\title{
Analisis Karakteristik Siswa Melalui Kuesioner/Angket Cinta Damai di kelas VII SMP 02 Muaro Jambi
}

\author{
Pujiono ${ }^{1}$, Aisyah Nur Hikmah ${ }^{2}$ \\ ${ }^{1}$ MTs N Pamenang, Merangin, Jambi. \\ ${ }^{2}$ Program Studi Pendidikan Fisika, Fakultas Keguruan dan Ilmu Pendidikan, Universitas Jambi \\ Aisyahnurhikmah16@gmail.com
}

\begin{abstract}
ABSTRAK
Tujuan dari penelitian ini adalah untuk mengetahui karakteristik cinta damai dari siswa yang ada di kelas VII SMP 02 Muaro Jambi dengan menggunakan sebuah kuesioner/angket yang berisi 25 pertanyaan, dimana disetiap pertanyaan telah disediakan poin 1-4. Penelitian ini dilakukan dengan cara observasi langsung ke sekolah yang akan dituju. Metode penelitian yang digunakan yaitu dengan pendekatan kuantitatif. Teknik analisis dari data tersebut dilakukan dengan perhitungan menggunakan aplikasi yang disebut SPSS. Data hasil dari penelitian ini menunjukkan jika data tersebut berdistribusi normal, yaitu nilai probabilitas 0,2>0,05. Hasil penelitian adalah : 1) Berdasarkan klasifikasi dari penghitungan data angket melalui SPSS dikelas VII C yaitu pada skor 62,51-81,25 ada 29 dari 30 siswa yang termasuk dan berada pada kategori "Sesuai". Namun sayangnya hanya 1 siswa yang berada pada rentang skor 81,26-100 dan bisa dibilang termasuk kategori "Sangat Sesuai". 2) Pada kelas VII F berdasarkan klasifikasi dari penghitungan data angket melalui SPSS dikelas VII F yaitu pada skor 43,76-62,5 terdapat 4 siswa yang termasuk kedalam kategori "Kurang sesuai", pada skor 62,51-81,25 ada 24 siswa yang termasuk dan berada pada kategori "Sesuai". Dan ada 2 siswa yang berada pada rentang skor 81,26-100 dan bisa dibilang termasuk kategori "Sangat Sesuai".
\end{abstract}

Kata kunci: Karakteristik siswa, Angket cinta damai

\section{ABSTRACT}

The purpose of this study was to find out the characteristics of peace-loving students who were in class VII of Muaro Jambi Middle School 02 by using a questionnaire / questionnaire containing 25 questions, in which points 1-4 were provided. This research was conducted by direct observation to the school to be addressed. The research method used is a quantitative approach. The analysis technique of the data is done by calculating using an application called SPSS. Data from the results of this study indicate if the data is normally distributed, namely a probability value of $0.2>0.05$. The results of the study are: 1) Based on the classification of the questionnaire data calculation through SPSS in class VII C which is in the score 62.51-81.25 there are 29 out of 30 students who are included and are in the "Appropriate" category. But unfortunately only 1 student is in the range of a score of 81.26-100 and arguably includes the category "Very Appropriate". 2) In class VII F based on the classification of the questionnaire data calculation through SPSS in class VII F which is a score of 43.76-62.5 there are 4 students who fall into the category of "Less suitable", in the score 62.51-81.25 there are 24 students who are included in the "Appropriate" category. And there are 2 students in the score range of 81.26-100 and can be categorized as "Very Appropriate".

Keywords: Student Characteristics, The Peace-loving Questionnaire

\section{PENDAHULUAN}

Pengendalian diri merupakan penetapan batasan bagi diri sendiri, yaitu bagaimana nantinya diri akan menolak untuk melakukan keinginan yang salah dan akan melakukan hal yang menurutnya benar. Kita semua tahu pendidikan pertama kita, kita dapatkan dari sebuah keluarga. Oleh karena itu, peran keluarga dapat dikatakan sangat diperlukan dalam tahap kogntif awal seseorang. Nilai-nilai karakter yang ada harus terlebih dahulu dimulai dari orang tua sebelum anak dapat memahaminya. Misalnya, orang tua harus berbicara dengan santun, sopan dan tidak mudah terpancing emosinya. Pengendalian diri sangat berhubungan 
dengan kebiasaan, cara terbaik yang dapat dilakukan oleh orang tua yaitu dengan menanamkan kebiasan yang baik dalam diri anak sedini mungkin. Memberikan pendidikan yang baik dan benar untuk mereka juga merupakan salah satu upaya yang dapat dilakukan agar mereka tidak terjerumus ke arah hal-hal yang negative(Servitri, 2017:79).

Pendidikan merupakan kebutuhan manusia. Pendidikan diharapkan mampu menghasilkan manusia yang berkualitas dan bertanggung jawab serta mampu menyongsong kemajuan pada masa yang akan datang. Menurut Isjoni (2006:19) Pendidikan adalah ujung tombak suatu negara, tertinggal atau majunya sebuah negara, sangat tergantung kondisi pendidikannya. Semakin berkembang pendidikan suatu negara, maka semakin besar dan majulah negara tersebut. Negara akan maju dan berkembang bila sector pendidikan sebagai kunci pembangunan menjadi skala prioritas. Negara besar dan berkembang menyadari bahwa pembangunan sector pendidikan sangat perlu dinomorsatukan. Pemerintah mereka tidak segan-segan menargetkan 30-40 persen dari anggaran belanja negara untuk sector pendidikan.

IPA merupakan mata pelajaran yang mempelajari peristiwa-peristiwa yang terjadi di alam. Menurut Sujana (2014:4) pengertian IPA dari yang didefinisikan oleh para ahli tersebut, dapat disimpulkan bahwa ilmu pengetahuan alam atau sains merupakan ilmu pengetahuan yang mempelajari mengenai alam semesta beserta isinya, serta peristiwaperistiwa yang terjadi di dalamnya yang di kembangkan oleh para akhli melalui serangkaian proses ilmiah yang dilakukan secara teliti dan hati-hati. Oleh karena itu, sains selalu berlndaskan pada observasi , baik dilakukan secara sistematik yang didukung oleh teori-teori sebelumnya maupun dengan spekulasi tanpa dukungan teori lain. Sebenarnya, dalam proses pengajaran sains yang baik sama seperti proses pengajaran yang lainnya. Baik atau tidaknya pembelajaran dapat dilihat dari sisi pemahaman dan pengetahuan siswa sebelumnya. Oleh karena itu, guru haruslah dapat memilih strategi pembelajaran yang sesuai(Azizah dan Winarti, 2018:234).

Sikap cinta damai dapat dikatakan sebagai sikap, perkataan, dan tindakan yang menyebabkan orang lain merasa senang dan aman atas kehadiran dirinya (Utomo, 2014:71-72). Damai dalam perspektif
Al-Qur'an bukan berarti tidak ada kekerasan atau perang (absence of war). Al-Qur'an menyuarakan bahwa damai lebih baik dari sekedar tidak adanya perang, akan tetapi ia merupakan pernyataan yang positif tentang keamanan dan manusia terbebas dari rasa ketakutan dan kegelisahan(Chaer, 2016:8485). Sikap cinta damai banyak mengajarkan siswa untuk tidak saling membenci yang dapat mengakibatkan perpecah belahan yang nantinya membuat membuat mereka saling dirugikan. Para siswa/siswi SMP 02 MUARO JAMBI memiliki sikap cinta damai terhadap sesamanya.

Penelitian ini bertujuan untuk mengetahui salah satu karakteristik siswa yaitu cinta damai, dimana pengambilan datanya dilakukan dengan cara pengisian kuesioner/angket terhadap siswa di SMP 02 MUARO JAMBI

\section{METODE PENELITIAN}

Penelitian ini termasuk penelitian deskriftif kuantitatif. Metode penelitian dengan pendekatan kuantitatif menjadi metode yang dipilih dalam penelitian ini yaitu untuk menjawab pertanyaanpertanyaan penelitian. Dalam penyusunan kuesioner yang digunakan adalah adalah bagaimana dapat melihat sikap cinta damai siswa terhadap siswa yang lain.

Menurut Arikunto (2013), penelitian deskriftif merupakan penelitian yang dimaksudkan untuk mengumpulkan informasi mengenai status suatu gejala yang ada, keadaan gejala menurut apa adanya pada saat penelitin dilakukan. Selain itu penelitian ini menggunakan pendekatan kuantitatif dengan maksud agar hasil yang didapatkan dapat diberlakukan secara umum yakni untuk populasi penelitian.

Penelitian ini dilakukan di SMPN 02 MUARO JAMBI, dengan objek penelitian adalah siswa/siswi kelas VII $\mathrm{C}$ dan VII $\mathrm{F}$ yang berjumlah kurang lebih 60 jiwa yang ada di SMPN tersebut. Yang menjadi populasi adalah siswa yang ada dikelas VII. Populasi adalah wilayah generalisasi yang terdiri atas obyek/subyek yang mempunyai kualitas dan karakteristik tertentu yang ditetapkan oleh peneliti untuk dipelajari dan kemudian ditarik kesimpulannya (Sugiyono, 2009). Penentuan ukuran sampel sering merupakan langkah penting dalam perencanaan studi statistik dan analisis item dan biasanya sulit. Diantara rintangan penting 
yang harus dilampaui, seseorang harus memperoleh perkiraan satu atau lebih variasi kesalahan, dan menentukan ukuran efek penting (Alwi:140)

Teknik pengumpulan data pada penelitian ini yaitu dengan cara peneliti melakukan pengambilan data dengan menggunakan kuesioner/angket untuk mengetahui seberapa besar tingkat cinta damai antar siswa terhadap teman sebayanya. Pada dasarnya kuesioner adalah sebuah daftar pertanyaan yang harus di isi oleh orang yang akan diukur (responden). Dengan kuesioner ini dapat diketahui tentang keadaan/data diri, pengalaman, pengetahuan sikap atau pendapatnya dan lain-lain (Arikunto,1984) dalam (Nugroho,dkk. 2017:199). Menurut Waluya (2007:95) angket adalah alat pengumpul data untuk kepentingan penelitian. Angket digunakan dengan cara mengedarkan formulir yang berisi beberapa pertanyaan kepada beberapa subjek (responden) untuk mendapat tanggapan secara tertulis. Sebelum angket disusun harus melalui prosedur sebagai berikut.

a. Merumuskan tujuan yang akan dicapai dengan angket

b. Mengidentifikasi variable sasaran angket.

c. Menjabarkan variable menjadi subvariabel menjadi spesifik dan tunggal.

d. Menentukan jenis data, sekaligus menentukan teknis analisisnya.

Dalam teknik analisis data, hasil data yang didapatkan nantinya akan di olah dengan menggunakan SPSS. Angket tersebut dianalisis dengan menggunakan statistic deskriptif. Analisis data ini tidak dapat dipisahkan dari topic dan data yang dikumpulkan. Apabila data yang dikumpulkan adalah data kuantitatif atau angka, maka gunakan teknik statistic yang terkait dan sesuai dengan jenis data yang dikupulkan, tetapi kalau datanya data kualitatif atau naratif, gunakan pula teknik yang dipakai dalam pendekatan kualitatif (Yusuf, 2017:17).

\section{HASIL \& PEMBAHASAN}

Hasil analisis data menggunakan uji normalitas. Uji normalitas digunakan untuk mengetahui apakah data-data tersebut berasal dari populasi sebaran atau distribusi normal. Uji normalitas data dalam penelitian ini dihitung dengan menggunakan SPSS 23. Untuk menolak atau menerima hipotesis dengan cara membandingkan nilai probabilitas dengan taraf signifikansi $(\alpha)=5 \%$. Jika nilai probabilitas lebih besar dari 0.05 maka dapat dinyatakan bahwa data berdistribusi normal

Tabel 1 Hasil perhitungan uji normalitas

\begin{tabular}{lccl} 
Variabel & Nilai Probabilitas & Nilai Signifikan & Keputusan \\
\hline Kelas VII C &, 200 & 0,05 & Normal \\
\hline Kelas VII F &, 200 & 0,05 & Normal \\
\hline
\end{tabular}

Dari hasil perhitungan uji normalitas diatas, menunjukkan bahwa semua nilai probabilitas dari data yaitu > dari 0,05 . Sehingga data tersebut dapat dibilang sebagai data berdistribusi normal. Dengan perhitungan menggunakan analisis deskriptif SPSS, didapatlah data dari angket cinta dama pada peserta didik kelas VII C SMPN 02 Muaro Jambi dapat dilihat pada tabel berikut:

Tabel 2. Data Angket Kelas VII C

\begin{tabular}{cc}
\hline Parameter & Hasil \\
\hline Mean & 70,7 \\
\hline Median & 70 \\
\hline Modus & 64 \\
\hline Standar Deviasi & 5,29 \\
\hline Minimum & 63 \\
\hline Maksimum & 84 \\
\hline Rentang & 21 \\
\hline
\end{tabular}

Tabel 3. Klasifikasi Data Angket Kelas VII C

\begin{tabular}{cccc}
\hline & Klasifikasi & & Persentase \\
\hline Skor & Kategori & frekuensi & $(\%)$ \\
\hline $25-43,75$ & $\begin{array}{c}\text { Sangat } \\
\text { tidak } \\
\text { sesuai }\end{array}$ & 0 & 0 \\
\hline $43,76-62,5$ & $\begin{array}{c}\text { tidak } \\
\text { sesuai }\end{array}$ & 0 & 0 \\
\hline $62,51-81,25$ & sesuai & 29 & 96,7 \\
\hline $81,26-100$ & $\begin{array}{c}\text { Sangat } \\
\text { sesuai }\end{array}$ & 1 & 3,3 \\
\hline Jumlah & & 30 & $100 \%$ \\
\hline
\end{tabular}

Sedangkan untuk data statistic deskriptif dan klasifikasi kelas VII F dapat dilihat pada tabel berikut ini : 
Tabel 4. Penghitungan dengan Statistik

\begin{tabular}{cc}
\hline Parameter & Hasil \\
\hline Mean & 72 \\
\hline Median & 73 \\
\hline Modus & 68 \\
\hline Standar Deviasi & 6,95 \\
\hline Minimum & 60 \\
\hline Maksimum & 85 \\
\hline Rentang & 25 \\
\hline
\end{tabular}

Tabel 5. Klasifikasi Data Angket Kelas VII F

\begin{tabular}{cccc}
\hline & Klasifikasi & & Persentase \\
\hline Skor & Kategori & frekuensi & $(\%)$ \\
\hline $25-43,75$ & $\begin{array}{c}\text { Sangat } \\
\text { tidak } \\
\text { sesuai }\end{array}$ & 0 & 0 \\
\hline $43,76-62,5$ & $\begin{array}{c}\text { tidak } \\
\text { sesuai }\end{array}$ & 4 & 13,3 \\
\hline $62,51-81,25$ & sesuai & 24 & 80,1 \\
\hline $81,26-100$ & $\begin{array}{c}\text { Sangat } \\
\text { sesuai }\end{array}$ & 2 & 6,6 \\
\hline \multicolumn{2}{c}{ Jumlah } & 30 & $100 \%$ \\
\hline
\end{tabular}

Penelitian ini dilakukan untuk mengetahui karakteristik cinta damai siswa yang dapat dilihat dari hasil data dengan menggunakan sebuah kuesioner/angket cinta damai.

Istilah tentang karakter dikemukakan oleh Thomas Lickona (1992) dengan menggunakan konsep karakter yang baik. Konsep mengenai karakter yang baik (good character) dulunya telah di perkenalkan lebih dulu oleh Thomas Lickona yang mengarah pada konsep yang dikemukakan oleh Aristoteles sebagai berikut “... the life of right conduct-right conduct in relation to other persons and in relation to oneself " atau kehidupan berperilaku baik/penuh kebajikan, yakni berperilaku baik ter-hadap pihak lain (Tuhan Yang Maha Esa, manu-sia, dan alam semesta) dan terhadap diri sendiri. Kehidupan yang penuh kebajikan (the virtuous life)sendiri oleh Lickona (1992) dibagi dalam dua kategori, yakni kebajikan terhadap diri sendiri (self-oriented virtuous) seperti pengendalian diri (self control) dan kesabaran (moderation); dan kebajikan terhadap orang lain (otheroriented virtuous), seper-ti kesediaan berbagi (generousity) dan merasakan kebaikan (compassion)(Khusniati, 2012:205).

\section{KESIMPULAN \& SARAN}

Setelah melakukan penelitan di SMPN 02 Muaro Jambi peneliti dapat menyimpulkan bahwa melalui kuesioner yang diberikan dapat dilihat bahwa siswa disekolah tersebut layak dikatakan sebagai siswa yang cinta damai terhadap sesamanya.

Dari tabel hasil diatas dapat disimpulkan bahwa. Hasil penelitiannya adalah : 1) Berdasarkan klasifikasi dari penghitungan data angket melalui SPSS dikelas VII C yaitu pada skor 62,51-81,25 ada 29 dari 30 siswa yang termasuk dan berada pada kategori "Sesuai". Namun sayangnya hanya 1 siswa yang berada pada rentang skor $81,26-100$ dan bisa dibilang termasuk kategori "Sangat Sesuai". 2) Pada kelas VII F berdasarkan klasifikasi dari penghitungan data angket melalui SPSS dikelas VII F yaitu pada skor 43,76-62,5 terdapat 4 siswa yang termasuk kedalam kategori "Kurang sesuai", pada skor $62,51-81,25$ ada 24 siswa yang termasuk dan berada pada kategori "Sesuai". Dan ada 2 siswa yang berada pada rentang skor 81,26100 dan bisa dibilang termasuk kategori "Sangat Sesuai".

Berdasarkan penelitian yang telah dilakukan maka peneliti ingin memberikan sedikit saran kepada sekolah, karena berdasarkan data tersebut maka rasa cinta damai terhadap sesama sudah baik. Diharapkan rasa cinta damai ini dapat di pertahankan agar tidak adanya kebencian atau emosi-emosi berlebihan terhadap sesama temannya

\section{DAFTAR PUSTAKA}

Alwi, Idrus. Kriteria Empirik dalam Menentukan Ukuran Sampel pada Pengujian Hipotesis statistika dan Analisis Butir. Jurnal Formatif 2(2). ISSN: 2088-35IX

Arikunto, S., 2013. Prosedur Penelitian, Suatu Pendekatan Praktik. Jakarta: Rineka Cipta.

Azizah, dan Puji Winarti. 2018. Pengembangan Modul Discon Sains Di Sekolah Dasar. Volume 8 Nomor 3 (hlm.234)

Isjoni. 2006. Pendidikan sebagai Investasi Masa Depan. Jakarta : Yayasan Pustaka Obor Indonesia

Khusniati, M. 2012. Pendidikan Karakter Melalui Pembelajaran IPA. Jurnal Pendidikan IPA Indonesia. PII 1 (2) (2012) 204-210 
Servitri, Ordo Margaretha. Pengaruh Teman Sebaya Terhadap Kemampuan Kognitif Siswa Berkesulitan Belajar Pada Pembelajaran IPA : Jurnal Publikasi Pendidikan. Volume 7 Nomor 2 (hlm. 79)

Sugiyono, 2009. Metode Penelitian Pendidikan (pendidikan kuantitatif, kualitatif dan $R \& D$ ). Bandung: Alfabeta

Sujana, Atep. 2014. Dasar-Dasar IPA: Konsep dan Aplikasinya. Bandung: UPI PRESS

Utomo, Tri. 2014. Berburu di Hutan Makna.Yogyakarta: Garudhawaca Online Books

Waluya, Bagja. 2007. Sosiologi: Menyelami Fenomena Sosial di Masyarakat. Bandung: PT Setia Purna Inves

Yusuf, Muri. 2017. Metode Penelitian: Kuantitatif, Kualitatif, dan Penelitian Gabungan. Jakarta: KENCANA 